\title{
Modification of the Estrogenic Properties of Diphenols by the Incorporation of Ferrocene. Generation of Antiproliferative Effects in Vitro
}

Anne Vessières, Siden Top, Pascal Pigeon, Elizabeth Hillard, Leila Boubeker, Daniela Spera, and Gérard Jaouen*

Laboratoire de Chimie et Biochimie des Complexes Moléculaires, UMR CNRS 7576, Ecole Nationale Supérieure de Chimie de Paris, 11, rue Pierre et Marie Curie, 75231 Paris Cedex 05, France

* To whom correspondence should be addressed. Phone: +33-1-43-26-95-55. Fax: +33-1-43-2600-61. E-mail: gerard-jaouen@enscp.fr.

\begin{abstract}
We report here the synthesis and the strong and unexpected antiproliferative effect of the organometallic diphenolic compound 1,1-bis(4'-hydroxyphenyl)-2-ferrocenyl-but-1-ene (4) on both hormone-dependent $(\mathrm{MCF} 7)$ and -independent $(\mathrm{MDA}-\mathrm{MB} 231)$ breast cancer cells $\left(\mathrm{IC}_{50}=\right.$ 0.7 and $0.6 \mu \mathrm{M})$. Surprisingly, 6 [1,2-bis(4'-hydroxyphenyl)-2-ferrocenyl-but-1-ene], the regioisomer of $\mathbf{4}$, shows only a modest effect on these cell lines. This pertinent organometallic modification seems to trigger an intracellular oxidation of the structurally favorable compound $\mathbf{4}$, leading to the generation of a potent cytotoxic compound.
\end{abstract}

Small polyphenolic molecules such as stilbenes, flavonoids, proanthocyanidines, and their derivatives are found throughout the vegetable world (for example, in grapes, green tea, and cocoa) and are recognized for their beneficial effects. ${ }^{1,2}$ Although they are most well-known for their antioxidant action ${ }^{3}$ against free radicals which have been associated with diseases related to aging (certain cancers, cardiac, ocular, and degenerative problems, etc.), ${ }^{4-6}$ these entities also act as specific modulators of certain protein functions. ${ }^{4,6}$ 
For example, resveratrol 1 (3,4',5-trihydroxy-trans-stilbene), present in red wine, is an endocrine modulator that recognizes estrogen receptors alpha and beta $(\operatorname{ER} \alpha$ and $\operatorname{ER} \beta),{ }^{7,8,9}$ as well as a free radical scavenger. ${ }^{10,11}$

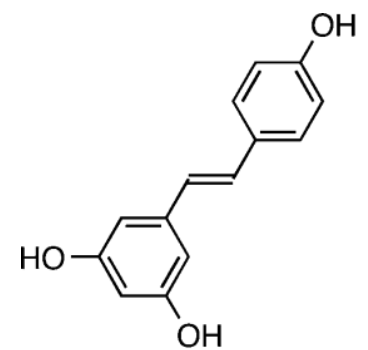

1: Resveratrol

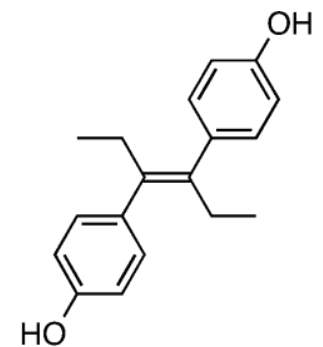

2 : DES

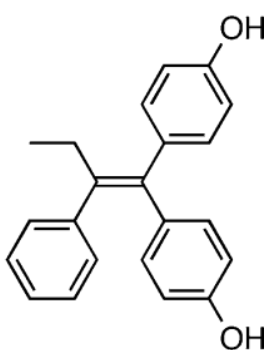

3

Another structurally similar stilbene, diethylstilbestrol (DES), 2 [(E)-3,4-(bis)(4'-hydroxyphenyl)3-hexene], can act as a powerful estrogen via $\mathrm{ER} \alpha$ and $\mathrm{ER} \beta{ }^{12}$ This compound was clinically prescribed from 1938 to 1971 for the prevention of pregnancy complications, but was subsequently prohibited due to its many adverse effects, including carcinogenicity and teratogenicity. ${ }^{13}$ In addition, the offspring of women treated by DES showed an increased incidence of reproductive and genital abnormalities. ${ }^{14}$ Among synthetic diphenolethylenes, compound 3, (1,1-bis(4'-hydroxyphenyl)-2-phenylbut-1-ene, likewise presents estrogenic effects, ${ }^{15,16}$ a feature that we have confirmed in our biological experiments to be discussed below.

As a part of our program investigating the biological activity of organometallic moieties tethered to selective estrogen receptor modulators, (SERMs), ${ }^{17-19}$ we have modified compounds $\mathbf{2}$ and $\mathbf{3}$ by incorporating a ferrocenyl substituent. Ferrocene is lipophilic, compact, stable in nonoxidizing media, and has shown some antitumor potential, albeit at rather high concentrations $\left(10^{-4} \mathrm{M}\right)$, when oxidized to the ferrocenium ion. ${ }^{20,21}$ Due to the receptor-mediated properties of 2 and 3, we hoped that their structures could act as vectors to facilitate the introduction of the potentially cytotoxic ferrocenyl group to cells containing the estrogen receptor. We show here, for the first time, that these known estrogenic properties can be profoundly modified, indeed reversed, by the grafting of an organometallic moiety to the organic diphenol skeleton. Furthermore, the addition of a ferrocenyl group generates surprising in vitro anti-proliferative effects on breast cancer cells classified as hormone-independent (ER $\alpha$ negative). These results are 
very significant as treatment of hormone-independent breast tumors suffers from few effective therapeutic solutions.

Scheme 1. Synthesis of Diphenols 3 and $\mathbf{4}$ by McMurry Cross-Coupling

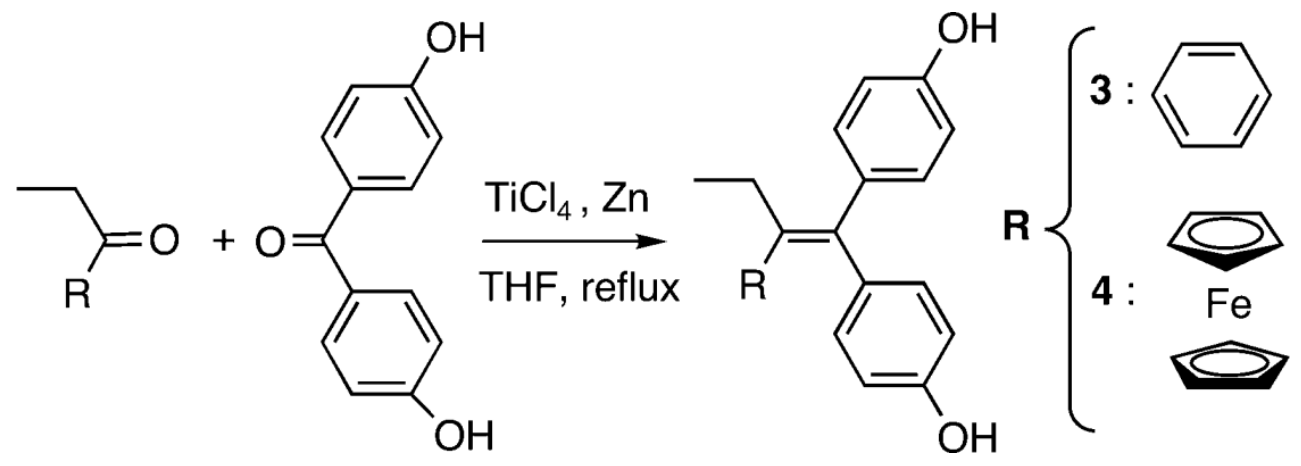

Scheme 2. Synthesis of Diphenol (Z)-6 via McMurry Cross-Coupling

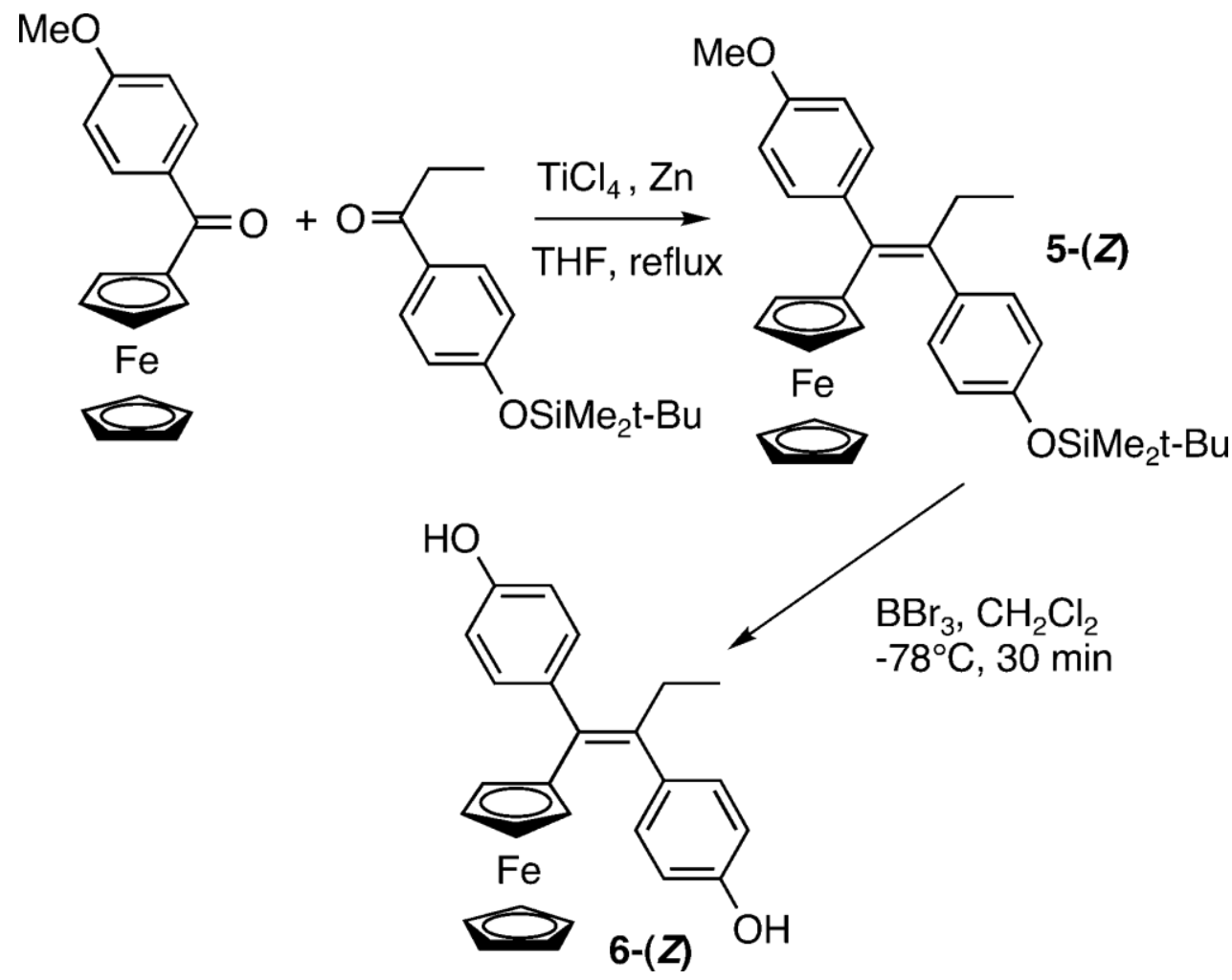

We found that a McMurry coupling ( $\left.\mathrm{Zn}, \mathrm{TiCl}_{4}, \mathrm{THF}\right)$ between the commercially available propiophenone and 4,4'-dihydroxybenzophenone allowed the direct synthesis of $\mathbf{3}$ with a yield, 
after purification and recrystallization, of $73 \%$ (Scheme 1). This synthesis is simpler than the five-step procedure described previously for $3 .^{15}$ This strategy was also used to obtain 4 in $53 \%$ yield. ${ }^{19}$ Finally, the McMurry coupling of 4-tert-butyldimethylsiloxyphenyl ethyl ketone and 4methoxyphenyl ferrocenyl ketone provided compound 5 in 74\% yield, as shown in Scheme 2. The coupling reaction was stereoselective; 5 was obtained mainly as the $Z$ isomer (Z/E: 93/7). The pure $(\mathrm{Z})$ isomer was separated by crystallization and identified by $2 \mathrm{D}$ NMR techniques (COSY, NOESY). The two protecting groups, methoxy and 4-tert-butyldimethylsiloxy, were eliminated simultaneously by $\mathrm{BBr}_{3}$, yielding (Z)-6, in $97 \%$ yield.

Table 1. Relative Binding Affinities (RBAs) for ER $\alpha$ (cytosol and purified), ER $\beta$ (purified) and Lipophilicity of the Diphenols Derivatives

\begin{tabular}{ccccc}
\hline \multirow{2}{*}{ compound } & \multicolumn{2}{c}{$\mathrm{RBA}\left(\mathrm{DMSO}, 0{ }^{\circ} \mathrm{C}, 3 \mathrm{~h} 30 \mathrm{~min}\right)^{a, b}$} & \\
\cline { 2 - 4 } $\operatorname{~ER~} \alpha$ (uterus) & $\mathrm{ER} \alpha($ purified $)$ & $\mathrm{ER} \beta$ & $\log P_{o / w}{ }^{c}$ \\
\hline $\mathbf{3}$ & $6.8 \pm 0.9$ & $47.5 \pm 5.8$ & $101 \pm 5$ & 4.4 \\
$\mathbf{6}$ & $9.6 \pm 0.9$ & $8.6 \pm 1.5$ & $16.3 \pm 1.5$ & 5.0 \\
\hline
\end{tabular}

${ }^{a} \mathrm{RBA}$ value of $\mathrm{E}_{2}$, the compound of reference is by definition equal to $100 \% .{ }^{b}$ Mean of at least two experiments. ${ }^{c}$ Measured by reversed-phase HPLC.

The relative binding affinity (RBA) values for the organic diphenol 3 and the organometallic diphenols 4 and $\mathbf{6}$ with respect to $\mathrm{ER} \alpha$ (from lamb uterine cytosol and purified) and $\operatorname{ER} \beta$ (purified) are reported in Table 1. All of the products showed an acceptable recognition for both forms of the receptor. The RBA values found for ER $\alpha$ from uterus and purified were similar for $\mathbf{4}$ and $\mathbf{6}$ (values between 9.6 and 5.4) while for $\mathbf{3}$ this value is significantly higher for purified $\mathrm{ER} \alpha$ (6.8 versus 47.5). This is probably due to higher nonspecific interactions of 3 in cytosol. The RBA values were at least twice as high for $\mathrm{ER} \beta$ than for $\mathrm{ER} \alpha$ with $\mathbf{3}$ showing a RBA value similar to that of estradiol. The lipophilicity was found to rise upon addition of the ferrocene 
unit, as expected, but the difference between the compounds is limited and thus could not account for the differences in biological activity.

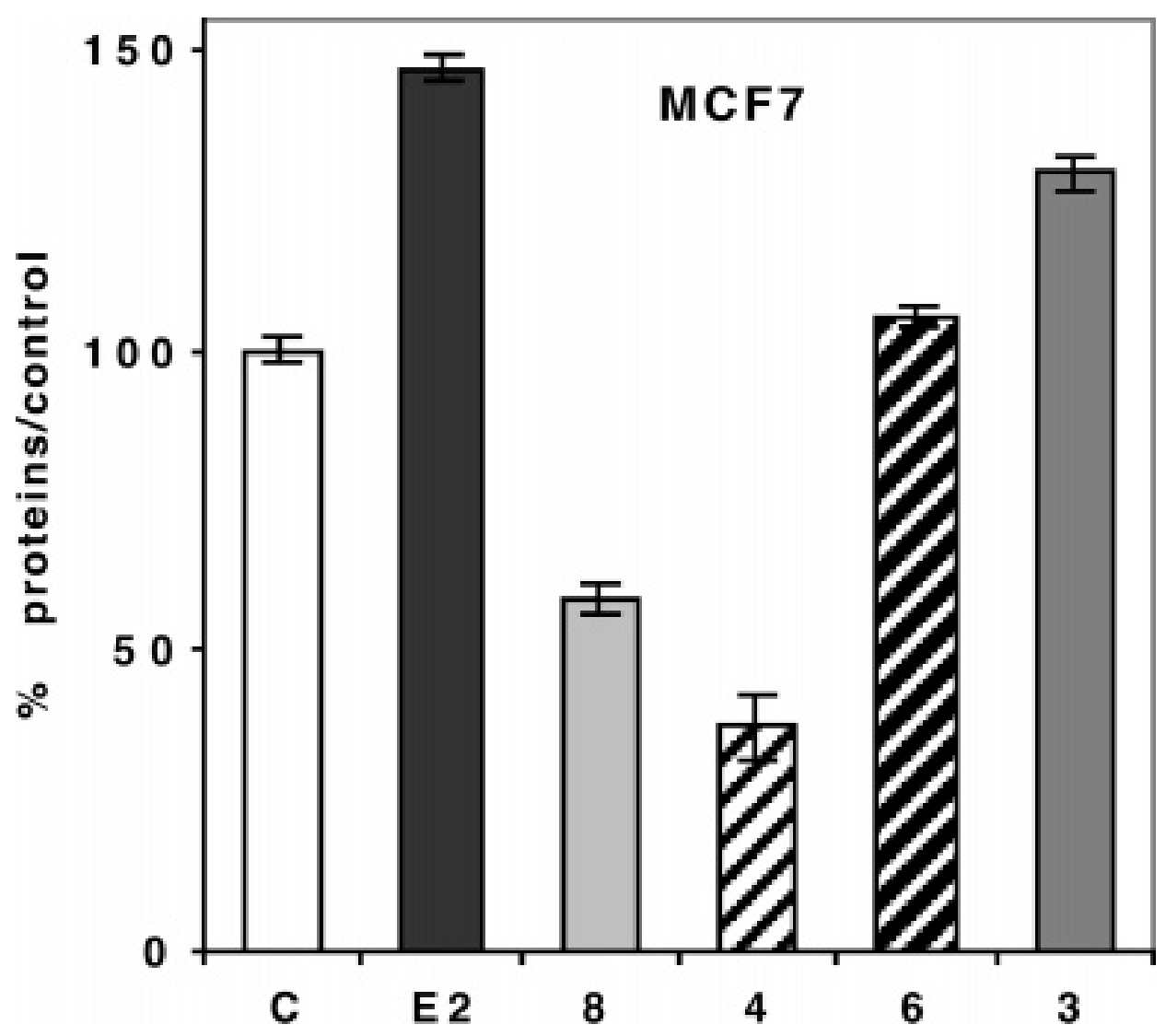

Figure 1. Effect of $1 \mu \mathrm{M}$ of 8 (OH-tamoxifen), 4, 6, 3 and of $10 \mathrm{nM}$ of estradiol $\left(\mathrm{E}_{2}\right)(\mathrm{C}=$ control) on MCF7 cells (breast cancer cell line, ER $\alpha$-positive) after 5 days of culture in medium with phenol red. Representative data of one experiment performed twice with similar results (eight measurements \pm limits of confidence; $P=0.1, t=1.895$ ). 


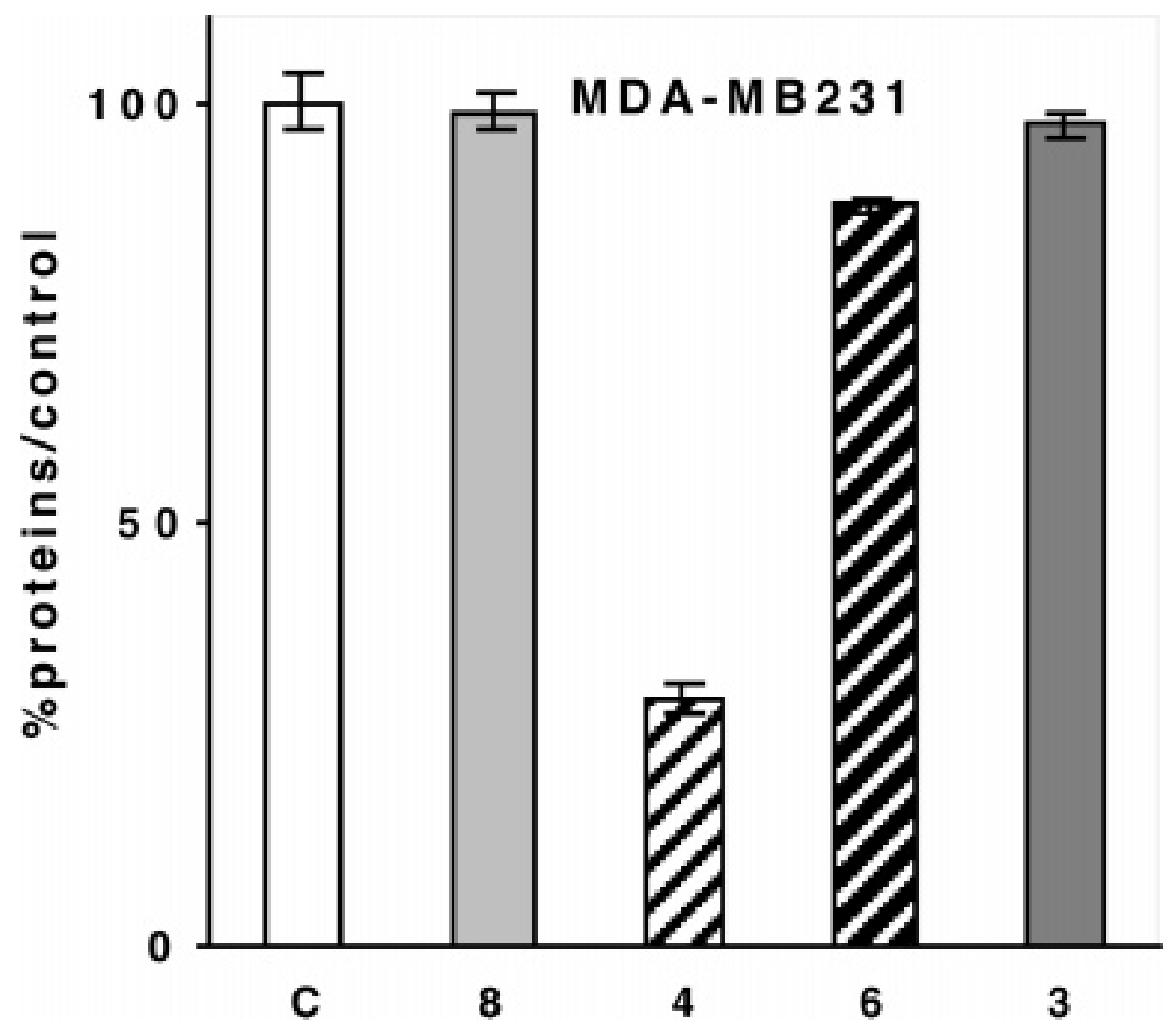

Figure 2. Effect of $1 \mu \mathrm{M}$ of $\mathbf{8}$ (OH-Tamoxifen), of the ferrocenyl diphenols $\mathbf{4}$ and $\mathbf{6}$, and of the organic phenol $3(\mathrm{C}=$ control) on MDA-MB231 cells (breast cancer cell line, $\mathrm{ER} \alpha$-negative) after 5 days of culture in medium without phenol red. Representative data of one experiment performed twice with similar results (eight measurements \pm limits of confidence; $P=0.1, t=1.895)$.

The proliferative/antiproliferative effects of $\mathbf{3}, \mathbf{4}$, and $\mathbf{6}$ at a concentration of $1 \mu \mathrm{M}$ were studied on hormone dependent (MCF7) and hormone-independent (MDA-MB231) breast cancer cell lines. The results are represented in Figures 1 and 2. For the hormone-dependent MCF7 breast cancer cells, in medium with phenol red, which is best suited for the expression of an antiestrogenic behavior, the two organometallic diphenols $\mathbf{4}$ and $\mathbf{6}$ showed rather different behavior. Whereas 6 displayed a slight proliferative effect, as one would predict from its diphenol ethylene structure, complex 4 showed a remarkably strong antiproliferative effect $\left(\mathrm{IC}_{50}=0.7 \mu \mathrm{M}\right)$. This antiproliferative effect was even stronger than that observed for 4-hydroxytamoxifen, the antiestrogen of reference. The strong antiproliferative effect of $\mathbf{4}$ was also observed in the hormone 
independent MDA-MB231 breast cancer cell line $\left(\mathrm{IC}_{50}=0.6 \mu \mathrm{M}\right)$, while compound $\mathbf{6}$ showed a very weak antiproliferative effect. Ferrocene alone has been previously shown to have no effect on these two cell lines. ${ }^{19}$ Finally, in a medium without phenol red which is best suited for the expression of an estrogenic behavior, the proliferative effect of $\mathbf{3}$ and $\mathbf{6}$ is stronger (respectively $173 \%$ and $145 \%$ of the control with $\mathrm{E}_{2}$ at $257 \%$ ) while 4 still shows an antiproliferative effect although less marked (73\% of the control).

Diphenol compounds 1-3 are known to be estrogenic, contributing to cell proliferation through interactions with the ER. In our experiments, compound 3 indeed showed a proliferative effect on the hormone dependent cells and had no significant effect on the hormone-independent cells. Conversely, ferrocene compounds, after oxidation to ferrocenium species, have been shown to be cytotoxic via generation of $\mathrm{OH}$ radical. These opposing properties have been combined to yield the ferrocenyl diphenols $\mathbf{4}$ and $\mathbf{6}$. Therefore there is competition between the two effects: a proliferative effect from the estrogenicity of the diphenol and an antiproliferative/cytotoxic effect from the ferrocenyl substituent. Compound $\mathbf{4}$ yielded strong antiproliferative effects in both hormone-dependent and -independent breast cancer cells, suggesting that the cytotoxic activity of the ferrocenyl group surpasses that of the estrogenic proliferative effect of the diphenol moiety. Surprisingly, 6 shows only a weak proliferative effect on MCF7 (ER positive) cells and a modest antiproliferative effect on MDA-MB231 (ER negative) cells. It is thus clear that the presence of a ferrocene group is necessary, but not sufficient, for the generation of antiproliferative effects, and that the positioning of the oxidizable ferrocenyl group is important. It should be noted that the increased activity of compound $\mathbf{4}$ cannot be solely attributed to higher receptor affinity, as the values for $\mathbf{4}$ and $\mathbf{6}$ are very similar for $\mathrm{ER} \alpha$, while the RBA is actually higher for $\mathbf{6}$ than for $\mathbf{4}$ for $\mathrm{ER} \beta$.

There are two notable structural differences between compounds $\mathbf{4}$ and $\mathbf{6}$. First, one of the two phenol groups is necessarily always oriented trans to the ferrocene group in compound 4, while there is a cis relationship between the ferrocene and phenol in compound $\mathbf{6}$. Second, the two phenol groups share the same carbon atom in $\mathbf{4}$, while, in compound $\mathbf{6}$, one phenol group resides on each of the alkene carbon atoms. As is clear from the disparate biochemical results for these compounds, cytotoxicity does not arise from the ferrocenyl group in isolation, and we must therefore consider ferrocene's influence on the organic portion of the molecule. It should 
be noted that the oxidation of SERMs such as tamoxifen and raloxifene to quinoids is a recognized pathway to cytotoxicity, ${ }^{22-24}$ and it is suggestive that the loss of two hydrogen atoms from compound $\mathbf{4}$ could theoretically yield quinone methide 7, Figure 3. It is possible that, in $\mathbf{4}$, the initial and easy oxidation of the ferrocenyl group to the ferrocenium radical cation promotes a transformation of the phenol group, and preliminary electrochemical results strongly support this hypothesis. $^{25}$ The transformation of a phenol to a quinoid via ferrocene oxidation has been reported in the literature, ${ }^{26}$ and current work to isolate oxidation products of compounds $\mathbf{4}$ and $\mathbf{6}$ is underway. The cytotoxicity of 7 would be the consequence of its sensitivity to nucleophilic attack as shown in other quinoid examples. ${ }^{22-24}$

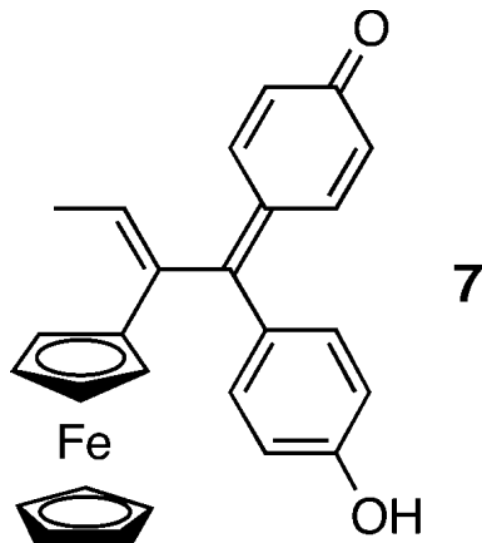

Figure 3. Putative cytotoxic quinone methide compound 7.

The proposed oxidative intracellular activation of compound $\mathbf{4}$ is further suggested by the observation that ER $\beta$ plays a role in controlling redox processes in the cell ${ }^{27}$ on the level of quinonases and in the mitochondria. ${ }^{28}$ In terms of the cytotoxic effect, the role of ER $\alpha$ can be excluded, as this receptor is not present in the MDA-MB231 cell line. However, ER $\beta$ is present in both the MCF7 and MDA-MB231 cells and may mediate the cytotoxic effect ${ }^{29}$ although this has not been proved. Should ER $\beta$, in fact, play a role in cell death, compounds such as $\mathbf{4}$ would be a much needed weapon against currently intractable ER negative breast tumors which are frequently $\operatorname{ER} \beta$ positive. ${ }^{30}$ Whatever is the actual mechanism, it remains that the powerful 
observed antiproliferative effects of compound 4 supply an impetus for the continued work in the burgeoning area of bioorganometallic chemistry.

Acknowledgment. We thank E. Salomon, A. Cordaville, and M. A. Plamont for technical assistance, M. N. Rager for determination of structures by 2D-NMR, and C. Barbaroux (Institut Curie, Paris) for the gift of cells. E.H. thanks NSF (grant no. 0302042) for financial support. D.S.'s stay in Paris was supported through a European Community Marie Curie Fellowship (HMPT-CT-2000-00186).

Supporting Information Available: Synthesis and complete characterization of 3, 4, and 6; experimental procedure for biochemical experiments. This material is available free of charge via the Internet at http://pubs.acs.org (or see the end of this file).

\section{References}

(1) Haslam, E. Practical Polyphenolics-From Structure to Molecular Recognition and Physiological Action; Cambridge University Press: Cambridge, 1998.

(2) Okuda, T.; Yoshida, T.; Hatano, T. Hydrolyzable tannins and related polyphenols. Prog. Chem. Org. Nat. Prod. 1995, 66, 1-117.

(3) Santos-Buelga, C.; Williamson, G. Methods in Polyphenol Analysis; RSC: Cambridge, 2003.

(4) Corder, R.; Douthwaite, J. A.; Lees, D. M.; Khan, N. Q.; Visen dos Santos, A. C.; Wood, E. E.; Carrier, M. J. Red wines confer extra benefit when it comes to preventing coronary heart disease. Nature 2001, 414, 863-864.

(5) Frémont, L. Biological effects of resveratrol. Life Sci. 2000, 66, 663-673. 
(6) Quideau, S. Plant Polyphenolic Small Molecules Can Induce a Calorie Restriction-Mimetic Life-Span Extension by Activating Sirtuins: Will Polyphenols Someday Be Used as Chemotherapeutic Drugs in Western Medicine? ChemBiochem 2004, 427-430.

(7) Mueller, S. O.; Simon, S.; Chae, K.; Metzler, M.; Korach, K. S. Phytoestrogens and their human metabolites show distinct agonistic and antagonistic properties on estrogen receptor alpha (ERalpha) and ERbeta in human cells. Toxicol. Sci. 2004, 80, 14-25.

(8) Bowers, J. L.; Tyulmenkov, V. V.; Jernigan, S. C.; Klinge, C. M. Resveratrol acts as a mixed agonist/antagonist for estrogen receptors alpha and beta. Endocrinology 2000, 141, 3657-3667.

(9) Gehm, B. D.; Levenson, A. S.; Liu, H.; Lee, E. J.; Amundsen, B. M.; Cushman, M.; Jordan, V. C.; Jameson, J. L. Estrogenic effects of resveratrol in breast cancer cells expressing mutant and wild-type estrogen receptors: role of AF-1 and AF-2. J. Steroid Biochem. Mol. Biol. 2004, 88, 223-234.

(10) M. J.; Duncan, J. Effects of trans-resveratrol on copper-dependent hydroxyl-radical formation and DNA damage: evidence for hydroxyl-radical scavenging and a novel, glutathione-sparing mechanism of action. Arch. Biochem. Biophys. 2000, 381, 253-263.

(11) Holmes-McNary, M.; Baldwin, A. S. J. Chemopreventive properties of trans-resveratrol are associated with inhibition of activation of the IkappaB kinase. Cancer Res. 2000, 60, 34773483.

(12) Van Lipzig, M. M. H.; ter Laak, A. M.; Jongejan, A.; Vermeulen, N. P. E.; Wamelink, M.; Geerke, D.; Meerman, J. H. N. Prediction of Ligand Binding Affinity and Orientation of Xenoestrogens to the Estrogen Receptor by Molecular Dynamics Simulations and the Linear Interaction Energy Method. J. Med. Chem. 2004, 47, 1018.

(13) Giusti, R. M.; Iwamoto, K.; Hatch, E. E. Diethylstilbestrol revisited: a review of the long-term health effects. Ann. Intern. Med. 1995, 122, 778-788.

(14) Schrager, S.; Potter, B. E. Diethylstilbestrol exposure. Am. Fam. Physician 2004, 69, 2395- 
2400.

(15) (a) Lubczyk, H.; Bachmann, R.; Gust, R. Antiestrogenically active 1,1,2-tris(4hydroxyphenyl)alkenes without basic side chain: synthesis and biological activity. J. Med Chem. 2003, 46, 1484-1491. (b) Schneider, M. R.; Von Angerer, E.; Schönenberger, H.; Michel, R. T.; Fortmeyer, H. P. 1,1,2-triphenylbut-1-enes: relationship between structure, estradiol receptor affinity, and mammary tumor inhibiting properties. J. Med. Chem. 1982, $25,1070-1077$.

(16) Stoessel, S.; Leclercq, G. Competitive binding assay for estrogen receptor in monolayer culture: measure of receptor activity potency. J. Steroid Biochem. 1986, 25, 677-682.

(17) Jaouen, G.; Top, S.; Vessières, A.; Leclercq, G.; McGlinchey, M. J. The first organometallic selective estrogen receptor modulators (SERMs) and their relevance to breast cancer. Curr. Med. Chem. 2004, 11, 2505-2517.

(18) Top, S.; Vessières, A.; Pigeon, P.; Rager, M. N.; Huché, M.; Salomon, E.; Cabestaing, C.; Vaissermann, J.; Jaouen, G. Selective estrogen receptor modulators (SERMs) in the cyclopentadienyl rhenium tricarbonyl series. Synthesis and Biological behaviour. ChemBioChem 2004, 5, 1104-1113.

(19) Top, S.; Vessières, A.; Leclercq, G.; Quivy, J.; Tang, J.; Vaissermann, J.; Huché, M.; Jaouen, G. Synthesis, biochemical properties and molecular modelling studies of organometallic specific estrogen receptor modulators (SERMs), the ferrocifens and hydroxyferrocifens: evidence for an antiproliferative effect of hydroxyferrocifens on both hormone-dependent and hormone-independent breast cancer cell lines. Chem. Eur. J. 2003, 9, 5223-5236.

(20) Osella, D.; Ferrali, M.; Zanello, P.; Laschi, F.; Fontani, M.; Nervi, C.; Cavigiolio, G. On the mechanism of the antitumor activity of ferrocenium derivatives. Inorg. Chim. Acta 2000, $306,42-48$.

(21) Tamura, H.; Miwa, M. DNA cleaving activity and cytotoxic activity of ferricenium cations. Chem. Lett. 1997, 1177-1178. 
(22) Fan, P. W.; Zhang, F.; Bolton, J. L. 4-hydroxylated metabolites of the antiestrogens tamoxifen and toremifene are metabolized to unusually stable quinone methides. Chem. Res. Toxicol. 2000, 13, 45-52.

(23) Zhang, F.; Fan, P. W.; Liu, X.; Shen, L.; van Breeman, R. B.; Bolton, J. L. Synthesis and reactivity of a potential carcinogenic metabolite of tamoxifen, 3,4-dihydroxytamoxifen-oquinone. Chem. Res. Toxicol. 2000, 13, 53-62.

(24) Yu, L.; Liu, H.; Li, W.; Zhang, F.; Luckie, C.; van Breemen, R. B.; Thatcher, G. R.; Bolton, J. L. Oxidation of raloxifene to quinoids: potential toxic pathways via a diquinone methide and o-quinones. Chem. Res. Toxicol. 2004, 17, 879-888.

(25) Amatore, C.; Hillard, E. A.; Jaouen, G.; Thouin, L.; Vessières, Ferrocene-mediated protoncoupled electron transfer in a series of ferrocifen-type breast cancer drug candidates. Manuscript in preparation.

(26) Kurihara, M.; Sano, H.; M., M.; Nishihara, H. Synthesis of a vinylene-bridged ferrocenehydroquinone complex and its unusual structural change originated by proton-coupled electron transfer. Inorg. Chem. 2001, 40, 4-5.

(27) Montano, M. M.; Jaiswal, A. K.; Katzenellenbogen, B. S. Transcriptional regulation of the human quinone reductase gene by antiestrogen-liganded estrogen receptor alpha and estrogen receptor beta. J. Biol. Chem. 1998, 273, 25443-25449.

(28) Yang, S. H.; Liu, R.; Perez, E. J.; Wen, Y.; Stevens, S. M.; Valencia, T.; BrunZinkernagel, A. M.; Prokai, L.; Will, Y.; Dykens, J.; Koulen, P.; Simpkins, J. W. Mitochondrial localization of estrogen receptor $\beta$. Proc. Natl. Acad. Sci. U.S.A. 2004, 101, 4130-4135.

(29) Vladusic, E. A.; Hornby, A. E.; Guerra-Vladusic, F. K.; Lupu, R. Expression of estrogen receptor $\beta$ messenger RNA variant in breast cancer. Cancer Res. 1998, 58, 210-214.

(30) Palmieri, C.; Cheng, G. J.; Saji, S.; Zelada-Hedman, M.; Wärri, A.; Weihua, Z.; Van Noorden, S.; Wahlstrom, T.; Coombes, R. C.; Warner, M.; Gustafsson, J. A. Estrogen 
receptor beta in breast cancer. Endocr. Relat. Cancer 2002, 9, 1-3. 


\section{Supporting Information}

\section{Contents :}

A- Chemical part :

- Elemental analysis (\%C, H, O) for compounds 3-6

- General data

- Experimental procedures for preparation of 3,4 and 6

B- Biochemical part :

- Materials

- Estrogen receptor sources

- Determination of the Relative Binding Affinity (RBA) of the compounds for ER $\alpha$ (from cytosol) ER $\alpha$ and ERß purified.

- Measurement of octanol/water partition coefficient $(\log \mathrm{Po} / \mathrm{w})$ of the compounds.

- Culture conditions

\section{A- Chemical part}

\section{Elemental analysis for compounds 3-6}

\begin{tabular}{|c|c|}
\hline Compounds & Elemental analysis \\
\hline $\mathbf{3}$ & $\left(\mathrm{C}_{22} \mathrm{H}_{20} \mathrm{O}_{2} \cdot 1 / 2 \mathrm{H}_{2} \mathrm{O}\right) \mathrm{C}, \mathrm{H}$ \\
\hline $\mathbf{4}$ & $\left(\mathrm{C}_{26} \mathrm{H}_{24} \mathrm{FeO}_{2}\right) \mathrm{C}, \mathrm{H}$ \\
\hline $\mathbf{5}$ & $\left(\mathrm{C}_{33} \mathrm{H}_{40} \mathrm{FeO}_{2} \mathrm{Si}\right) \mathrm{C}, \mathrm{H}$ \\
\hline $\mathbf{6}$ & $\left(\mathrm{C}_{26} \mathrm{H}_{24} \mathrm{FeO}_{2} \cdot 1 / 4 \mathrm{H}_{2} \mathrm{O}\right) \mathrm{C}, \mathrm{H}$ \\
\hline
\end{tabular}


General Data. Starting materials were synthesized using standard Schlenk techniques, under an argon atmosphere. Anhydrous THF and diethyl ether were distilled from sodium/benzophenone. Thin layer chromatography was performed on silica gel $60 \mathrm{GF} 254 .{ }^{1} \mathrm{H}$ and ${ }^{13} \mathrm{C}$ NMR spectra were acquired on Bruker 200 and Bruker 400 spectrometers by using $\mathrm{CDCl}_{3}$ as a solvent. High resolution mass spectrometry was performed on a Geol MS spectrometer. Melting points were measured with a Kofler device. Elemental analyses were performed by the Regional Microanalysis Department of Université Pierre et Marie Curie and all values were within $\pm 0.4 \%$.

\section{Experimental procedures for preparation of 3, 4 and 6}

Synthesis of 3, 1,1-bis(4-hydroxyphenyl)-2-phenyl-but-1-ene. $\mathrm{TiCl}_{4}(3.11 \mathrm{~g}, 16 \mathrm{mmol})$ was added dropwise to a suspension of zinc powder $(2.00 \mathrm{~g}, 31 \mathrm{mmol})$ in $60 \mathrm{ml}$ of THF at $0^{\circ} \mathrm{C}$. The dark grey mixture obtained was heated at reflux for $2 \mathrm{~h}$. A solution of THF ( $40 \mathrm{ml})$ containing 4,4'-dihydroxybenzophenone $(1.07 \mathrm{~g}, 5 \mathrm{mmol})$ and propiophenone $(0.67 \mathrm{~g}, 5 \mathrm{mmol})$ was added dropwise to the first solution and the resulting mixture was heated for $2 \mathrm{~h}$. After cooling to room temperature, the mixture was stirred with water and $\mathrm{CH}_{2} \mathrm{Cl}_{2}$. The mixture was then acidified by addition of diluted $\mathrm{HCl}$ and decanted. The crude product was chromatographed on silica gel column with $\mathrm{CH}_{2} \mathrm{Cl}_{2} /$ acetone 95:5 as eluent. 3 was recrystallized from ethanol/water, $73 \%$ yield (m.p. $\left.203^{\circ} \mathrm{C}\right) .{ }^{1} \mathrm{H}$ NMR $\left(300 \mathrm{MHz}, \mathrm{CD}_{3} \mathrm{OD}\right) \delta$ 7.20-7.05 (m, 5H, $\left.\mathrm{C}_{6} \mathrm{H}_{5}\right), 7.05(\mathrm{~d}, 2 \mathrm{H}, \mathrm{J}=8.5 \mathrm{~Hz}$, $\left.\mathrm{C}_{6} \mathrm{H}_{4}\right), 6.80\left(\mathrm{~d}, 2 \mathrm{H}, \mathrm{J}=8.5 \mathrm{~Hz}, \mathrm{C}_{6} \mathrm{H}_{4}\right), 6.69\left(\mathrm{~d}, 2 \mathrm{H}, \mathrm{J}=8.5 \mathrm{~Hz}, \mathrm{C}_{6} \mathrm{H}_{4}\right), 6.43(\mathrm{~d}, 2 \mathrm{H}, \mathrm{J}=8.5 \mathrm{~Hz}$, $\left.\mathrm{C}_{6} \mathrm{H}_{4}\right), 2.51\left(\mathrm{q}, 2 \mathrm{H}, \mathrm{J}=7.4 \mathrm{~Hz}, \mathrm{CH}_{2}\right), 0.94\left(\mathrm{t}, 3 \mathrm{H}, \mathrm{J}=7.4 \mathrm{~Hz}, \mathrm{CH}_{3}\right.$ ). HRMS: Calcd for $\mathrm{C}_{22} \mathrm{H}_{21} \mathrm{O}_{2}$ $\left(\mathrm{MH}^{+}\right), 317.1542$, found, 317.1540 .

Synthesis of 4, 1,1-bis(4-hydroxyphenyl)-2-ferrocenyl-but-1-ene. $\mathrm{TiCl}_{4}(5.70 \mathrm{~g}, 30 \mathrm{mmol})$ was added dropwise to a suspension of zinc powder $(3.90 \mathrm{~g}, 60 \mathrm{mmol})$ in $60 \mathrm{ml}$ of THF at $0^{\circ} \mathrm{C}$. The dark grey mixture obtained was heated at reflux for $2 \mathrm{~h}$. A solution of THF (30 ml) containing 4,4'-dihydroxybenzophenone $(2.14 \mathrm{~g}, 10 \mathrm{mmol})$ and ferrocenyl ethyl ketone ( $2.42 \mathrm{~g}$, $10 \mathrm{mmol}$ ) was added dropwise to the first solution and the resulting mixture was heated for $2 \mathrm{~h}$. After cooling to room temperature, the mixture was hydrolyzed with $200 \mathrm{ml}$ of a $10 \% \mathrm{Na}_{2} \mathrm{CO}_{3}$ 
solution. After ether extraction and solvent removal, the crude product was chromatographed on a silica gel column with ethyl ether/pentane 1:2 as eluent. $2.23 \mathrm{~g}$ of $\mathbf{4}$ were isolated, orange solid, $52 \%$ yield (m.p. $\left.219^{\circ} \mathrm{C}\right) .{ }^{1} \mathrm{H}$ NMR $\left(200 \mathrm{MHz}, \mathrm{CDCl}_{3}\right) \delta 7.08$ and $6.80(\mathrm{~d}, \mathrm{~d}, 2 \mathrm{H}, 2 \mathrm{H}, \mathrm{J}=8.5 \mathrm{~Hz}$, $\left.\mathrm{C}_{6} \mathrm{H}_{4}\right), 6.90$ and $6.68\left(\mathrm{~d}, \mathrm{~d}, 2 \mathrm{H}, 2 \mathrm{H}, \mathrm{J}=8.5 \mathrm{~Hz}, \mathrm{C}_{6} \mathrm{H}_{4}\right), 5.04$ (s broad, 2H, OH), 4.11 (s, 5H, Cp), 4.07 and 3.90 (t,t, 2H, 2H, $\left.\mathrm{C}_{5} \mathrm{H}_{4}\right), 2.58\left(\mathrm{q}, 2 \mathrm{H}, \mathrm{J}=7.5 \mathrm{~Hz}, \mathrm{CH}_{2}\right), 1.02\left(\mathrm{t}, 3 \mathrm{H}, \mathrm{J}=7.5 \mathrm{~Hz}, \mathrm{CH}_{3}\right)$.

Synthesis of 5, (1-(4-t-butyldimethylsiloxyphenyl)-2-(4-methoxyphenyl)-2ferrocenyl-but1-ene). $\mathrm{TiCl}_{4}(1.07 \mathrm{~g}, 5.63 \mathrm{mmol})$ was added dropwise to a suspension of $0.736 \mathrm{~g}(11.26 \mathrm{mmol})$ of zinc powder in $18 \mathrm{ml}$ of $\mathrm{THF}$ at $0^{\circ} \mathrm{C}$. The dark grey mixture obtained was heated at reflux for $2 \mathrm{~h}$. A solution of THF (3.6 ml) containing 4-t-butyldimethylsiloxyphenyl ethyl ketone $(0.496 \mathrm{~g}$, $1.88 \mathrm{mmol})$ and 4-methoxy phenyl ferrocenyl ketone $(0.300 \mathrm{~g}, 0.94 \mathrm{mmol})$ was added dropwise to the first solution and then the resulting mixture was heated for $2 \mathrm{~h}$. After cooling to room temperature, the mixture was hydrolyzed with $50 \mathrm{ml}$ of a $10 \% \mathrm{~K}_{2} \mathrm{CO}_{3}$ solution. After ether extraction and solvent removal, the crude product was chromatographed on a silica gel column with $\mathrm{CH}_{2} \mathrm{Cl}_{2}$ /pentane 1:3 as eluent. $0.383 \mathrm{~g}$ of 5 was isolated, orange solid, $74 \%$ yield. NMR spectrum shows mainly one major isomer that was isolated in pure form by crystallization in ether/pentane (m.p. $113^{\circ} \mathrm{C}$ ). ${ }^{1} \mathrm{H}$ NMR (400 MHz, $\left.\mathrm{CDCl}_{3}\right): \delta 7.24$ and $6.98(\mathrm{~d}, \mathrm{~d}, 2 \mathrm{H}, 2 \mathrm{H}$, $\mathrm{C}_{6} \mathrm{H}_{4} \mathrm{OMe}$ ); 7.07 and $6.90\left(\mathrm{~d}, \mathrm{~d}, 2 \mathrm{H}, 2 \mathrm{H}, \mathrm{C}_{6} \mathrm{H}_{4} \mathrm{OSi}\right), 3.98$ (s, 5H, Cp), 3.90 (t, 2H, $\left.\mathrm{C}_{5} \mathrm{H}_{4}\right), 3.89$ (s, $3 \mathrm{H}, \mathrm{OMe}), 3.30\left(\mathrm{~s}, 2 \mathrm{H}, \mathrm{C}_{5} \mathrm{H}_{4}\right), 2.05\left(\mathrm{q}, 2 \mathrm{H}, \mathrm{CH}_{2}\right), 1.03$ (s, 9H, t-Bu), 0.77 (t, 3H, $\left.\mathrm{CH}_{3}\right), 0.25(\mathrm{~s}$, $\left.6 \mathrm{H}, 2 \mathrm{CH}_{3}\right) .{ }^{13} \mathrm{C} \mathrm{NMR}\left(50 \mathrm{MHz}, \mathrm{CDCl}_{3}, \mathrm{ppm}\right): \delta 158.1$ and $154.4\left(\mathrm{C}, \mathrm{C}_{6} \mathrm{H}_{4}\right), 140.6$ and 136.3 $(\mathrm{C}=\mathrm{C}), 134.8$ and $134.0\left(\mathrm{C}, \mathrm{C}_{6} \mathrm{H}_{4}\right), 130.5$ and $130.3\left(\mathrm{CH}, \mathrm{C}_{6} \mathrm{H}_{4}\right), 120.3$ and $113.2\left(\mathrm{CH}, \mathrm{C}_{6} \mathrm{H}_{4}\right)$, 70.9 and $69.6\left(\mathrm{C}_{5} \mathrm{H}_{4}\right), 70.3(\mathrm{Cp}), 55.3(\mathrm{OMe}), 30.6\left(\mathrm{CH}_{2}\right), 25.8(\mathrm{t}-\mathrm{Bu}), 13.1\left(\mathrm{CH}_{3}\right),-4.3\left(2 \mathrm{CH}_{3}\right)$. The structure of 5 was determined by 2D NMR techniques (COSY, NOESY). The NOESY spectrum showed a nuclear Overhauser interaction between $\left(\eta^{5}-\mathrm{C}_{5} \mathrm{H}_{4}\right)$ protons of ferrocenyl (3.30 $\mathrm{ppm})$ with the siloxyphenyl ring protons $(7.07 \mathrm{ppm})$ proving that these two groups are located in cis position. The structure was also confirmed by the absence of interaction between the two aromatic rings. $\mathrm{MS}(\mathrm{EI}): \mathrm{m} / \mathrm{z}=552\left(\mathrm{M}^{+}\right), 487(\mathrm{M}-\mathrm{Cp})^{+}, 471,248,121,73,59$.

Synthesis of 6, 1,2-bis(4-hydroxyphenyl)-2-ferrocenyl-but-1-ene. Compound 5 (0.10 g, $0.23 \mathrm{mmol})$ was dissolved in $2 \mathrm{~mL}$ of distilled $\mathrm{CH}_{2} \mathrm{Cl}_{2}$. After cooling to $-80^{\circ} \mathrm{C}, \mathrm{BBr}_{3}(0.02 \mathrm{~mL}$, $0.23 \mathrm{mmol}$ ) was added dropwise. The cooling bath was removed and the mixture was stirred for 30 min. It was then hydrolyzed with $10 \mathrm{~mL}$ of iced water and the organic compounds were 
extracted with $3 \times 40 \mathrm{~mL}$ of $\mathrm{CH}_{2} \mathrm{Cl}_{2}$. The $\mathrm{CH}_{2} \mathrm{Cl}_{2}$ solution was first washed with $\mathrm{Na}_{2} \mathrm{~S}_{2} \mathrm{O}_{3}$ and then with $10 \mathrm{~mL}$ of water. After drying over $\mathrm{MgSO}_{4}$ and solvent removal, the crude product was chromatographed on silica gel plates with ethyl ether/pentane 1:1 as eluent. $0.094 \mathrm{~g}$ of 6 were isolated, orange solid, $97 \%$ yield $\left(\mathrm{Rf}=0.42\right.$, m.p. $\left.206-210^{\circ} \mathrm{C}\right) .{ }^{1} \mathrm{H}$ NMR $\left(200 \mathrm{MHz}\right.$, Acetone- $\left.\mathrm{d}_{6}\right)$ : $\delta 7.07$ (d, J=8.2 Hz, 4H, Harom), 6.95 and 6.90 (d, d, J = 8.2 Hz, 2H, 2H, $\mathrm{H}_{\text {arom }}$ ), 4.15 (s, 5H, Cp), $4.10\left(\mathrm{t}, 2 \mathrm{H}, \mathrm{C}_{5} \mathrm{H}_{4}\right), 3.17\left(\mathrm{t}, 2 \mathrm{H}, \mathrm{C}_{5} \mathrm{H}_{4}\right), 2.11\left(\mathrm{q}, 2 \mathrm{H}, \mathrm{CH}_{2}\right), 0.75\left(\mathrm{t}, 3 \mathrm{H}, \mathrm{CH}_{3}\right) .{ }^{13} \mathrm{C} \mathrm{NMR}(50 \mathrm{MHz}$, Acetone- $\left.\mathrm{d}_{6}\right): \delta 157.1$ and $156.7\left(\mathrm{C}, \mathrm{C}_{6} \mathrm{H}_{4}\right), 140.6,135.5,135.3,134.6(\mathrm{C}), 131.2$ and $131.1(\mathrm{CH}$, $\left.\mathrm{C}_{6} \mathrm{H}_{4}\right), 116.1$ and $115.5\left(\mathrm{CH}, \mathrm{C}_{6} \mathrm{H}_{4}\right), 71.0(\mathrm{Cp}), 70.5\left(\mathrm{C}_{5} \mathrm{H}_{4}\right), 69.5\left(\mathrm{C}_{5} \mathrm{H}_{4}\right), 31.3\left(\mathrm{CH}_{2}\right), 13.3\left(\mathrm{CH}_{3}\right)$. MS (EI) : m/z= $424\left(\mathrm{M}^{+}\right), 395(\mathrm{M}-\mathrm{Et})^{+}, 357(\mathrm{M}-\mathrm{Cp})^{+}$, 343, 291, 179, 121, 77, 56. HRMS: Calcd for $\mathrm{C}_{26} \mathrm{H}_{25} \mathrm{FeO}_{2}\left(\mathrm{MH}^{+}\right)$, 425.1204, found, 425.1199.

\section{B- Biochemical part :}

\section{Purity of the compounds :}

The purity of the compounds tested in biochemical experiments (i.e. $\mathbf{3}, \mathbf{4}$ and $\mathbf{6}$ ) was checked by reversed phase HPLC on a chromasil C18 column (10 microns, L=25cm, D=4.6 mm) eluted with a mixture acetonitrile/water (80/20) and measurement of the absorbance at $254 \mathrm{~nm}$.

Materials : 17ß-Estradiol, 4-OH-Tam (Z), glutamine, protamine sulfate were obtained from Sigma-Aldrich (France). Stock solutions $\left(1 \times 10^{-3} \mathrm{M}\right)$ of the compounds to be tested were prepared in DMSO and were kept at $4^{\circ} \mathrm{C}$ in the dark; under these conditions they are stable at least two months. Serial dilutions in ethanol were prepared just prior to use. Dulbecco's modified eagle medium (DMEM) was purchased from Gibco BRL, fetal calf serum from Dutscher, Brumath, France. MCF7 and MDA-MB231 cells were from Human Tumor Cell Bank.

Estrogen receptor sources : Sheep uteri weighing approximately $7 \mathrm{~g}$ were obtained from the slaughterhouse at Mantes-la-Jolie, France. They were immediately frozen and kept in liquid nitrogen prior to use. Purified ER $\alpha$ and $E R ß$ were from Invitrogen corporation.

\section{Determination of the Relative Binding Affinity (RBA) of the compounds for ERa (from} cytosol), ERa and ERß purified: Sheep uterine cytosol prepared in buffer A (0.05 M TrisHCL, $0.25 \mathrm{M}$ sucrose, $0.1 \%$ B-mercaptoethanol, pH 7.4 at $25^{\circ} \mathrm{C}$ ) as described in (Vessières, A.; Top, S.; 
Ismail, A. A.; Butler, I. S.; Loüer, M.; Jaouen, G. Organometallic estrogens: synthesis, interaction with lamb uterine estrogen receptor, and detection by infrared spectroscopy. Biochemistry 1988, 27, 6659-6666) was used as a source of cytosolic ER $\alpha$. For ER $\alpha$ and ERß purified, $10 \mu 1$ of the solution containing $3500 \mathrm{pmol} / \mathrm{ml}$ were added to $16 \mathrm{ml}$ of buffer B (10\% glycerol, $50 \mathrm{mM}$ BisTris-Propane $\mathrm{pH}=9,400 \mathrm{mM} \mathrm{KCl}, 2 \mathrm{mM}$ DTT, $1 \mathrm{mM}$ EDTA, 0.1\% BSA) in a silanised flask. Aliquots $(200 \mu \mathrm{l})$ of ER $\alpha$ in glass tubes or ERß in polypropylene tubes were incubated for $3 \mathrm{~h}$ at $0^{\circ} \mathrm{C}$ with [6,7-3H]-estradiol $\left(2 \times 10^{-9} \mathrm{M}\right.$, specific activity $1.62 \mathrm{TBq} / \mathrm{mmol}$, NEN Life Science, Boston MA) in the presence of nine concentrations of the hormones to be tested. At the end of the incubation period, the free and bound fractions of the tracer were separated by protamine sulfate precipitation. The percentage reduction in binding of $[3 \mathrm{H}]$-estradiol $(\mathrm{Y})$ was calculated using the logit transformation of $\mathrm{Y}(\operatorname{logit} \mathrm{Y}: \ln [\mathrm{y} / 1-\mathrm{Y}]$ versus the $\log$ of the mass of the competing steroid. The concentration of unlabeled steroid required to displace $50 \%$ of the bound $[3 \mathrm{H}]$-estradiol was calculated for each steroid tested, and the results expressed as RBA. The RBA value of estradiol is by definition equal to $100 \%$.

\section{Measurement of octanol/water partition coefficient $(\operatorname{logPo} / w)$ of the compounds: The} $\log \mathrm{Po} / \mathrm{w}$ values of the compounds were determined by reversed-phase HPLC on a C-8 column (nucleosil 5.C8, from Macherey Nagel, France) according to the method previously described by Minick (Minick, D. J.; Frenz, J. H.; Patrick, M. A.; Brent, D. A. A comprehensive method for determining hydrophobicity constants by reversed-phase high-performance liquid chromatography. J. Med. Chem. 1988, 31, 1923-1933) and Pomper (Pomper, M. G.; VanBrocklin, H.; Thieme, A. M.; Thomas, R. D.; Kiesewetter, D. O.; Carlson, K. E.; Mathias, C. J.; Welch, M. J.; Katzenellenbogen, J. A. 11ß-Methhoxy, 11ß-Ethyl- and 17alphaEthynylsubstituted 16alpha-Fluoroestradiols: receptor based imaging agents with enhanced uptake efficiency and selectivity. J. Med. Chem. 1990, 33, 3143-3155). Measurement of the chromatographic capacity factors $\left(k^{\prime}\right)$ for each compounds was done at various concentrations in the range $85 \%$ - $60 \%$ methanol (containing $0.25 \%$ octanol) and an aqueous phase consisting of 0.15\% n-decylamine in 0.02 M MOPS (3-morpholino propanesulfonic acid) buffer $\mathrm{pH} 7.4$ (prepared in 1-octanol-saturated water). These capacity factors (k') are extrapolated to $100 \%$ of the aqueous component given the value of $\mathrm{k}^{\prime} \mathrm{w} \cdot \log \mathrm{Po} / \mathrm{w}(\mathrm{y})$ is then obtained by the formula : $\log \mathrm{Po} / \mathrm{w}=0.13418+0.98452 \log \mathrm{k}^{\prime} \mathrm{w}$. 
Culture conditions : Cells were maintained in monolayer in DMEM with phenol red (Gibco BRL) supplemented with 8-9\% fetal calf serum (Gibco BRL) and glutamine $2 \mathrm{mM}$ (Sigma) at $37^{\circ} \mathrm{C}$ in a $5 \% \mathrm{CO}_{2}$ air humidified incubator. For proliferation assays, cells were plated in $1 \mathrm{~mL}$ of DMEM medium with or without phenol red for MCF7 cells and without phenol red for MDA MB231 cells, supplemented with 10\% decomplemented and hormone-depleted fetal calf serum and $2 \mathrm{mM}$ glutamine and incubated. The following day $\left(\mathrm{D}_{0}\right) 1 \mathrm{ml}$ of the same medium containing the compounds to be tested was added to the plates (final volumes of alcohol : $0,1 \% ; 8$ wells for each conditions, one plate per day, 3 molarities : $0.1 \mu \mathrm{M}, 0.5 \mu \mathrm{M}, 1 \mu \mathrm{M}$ for $\mathrm{IC}_{50}$ determination). After 3 days $\left(D_{3}\right)$ the incubation medium was removed and fresh medium containing the compounds was added. After 5 days $\left(\mathrm{D}_{5}\right)$ the total protein content of the plate was analyzed by methylene blue staining as follows. Cell monolayers were fixed for $1 \mathrm{~h}$ in methanol, stained for 1 $\mathrm{h}$ with methylene blue $(1 \mathrm{mg} / \mathrm{mL})$ in PBS, then washed thorougly with water. One $\mathrm{ml}$ of $\mathrm{HCl}(0.1$ M) was then added and the absorbance of each well was measured at $620 \mathrm{~nm}$ with a Biorad spectrophotometer. The results are expressed as the percentage of proteins versus the control. Three different concentrations $\left(1 \times 10^{-7} \mathrm{M}, 5 \times 10^{-7} \mathrm{M}, 1 \times 10^{-6} \mathrm{M}\right)$ were used to determine graphically $\mathrm{IC}_{50}$ values (concentration causing $50 \%$ inhibition of cell proliferation). The indicated value was the mean of two independent experiments. 